\title{
QUASI-ARITHMETIC MEANS AND SUBQUADRACITY
}

\section{SHOSHANA ABRAMOVICH}

Abstract. The inequalities derived in this article for quasi-arithmetic means and power means are related to subquadratic and superquadratic functions.

Mathematics subject classification (2010): Primary 26D15, 47A63, 47A64; Secondary 26A51.

Keywords and phrases: Subquadratic functions, convex functions, Jesen's inequality, quasi-arithmetic means, power means.

\section{REFERENCES}

[1] S. Abramovich, On superquadracity, J. Math. Ineq. 3, (2009), 329-239.

[2] S. Abramovich, M. Klaričić Bakula, M. Matić, and J. Pečarić, A variant of JensenSteffensen's inequality and quasi-arithmetic means, J. Math. Anal. Appl. 307 (2005) 370-386.

[3] S. Abramovich, J. PeČArić, And S. Varošanec, Comparison theorems between several quasiarithmetic means, Math. Inequal. Appl. 7 (2004) 1-6.

[4] R. BIBI, M. BOHNER AND J. PeČARIĆ, Cauchy type means and exponential and logarithmic convexity for superquadratic functions on time scale, to appear, Ann. Func. Anal.

[5] P. S. Bullen, D. S. Mitrinović And P. M. VAsić, Means and their inequalities, Reidel, Dordrecht 1988.

[6] A. MCD. MERCER, A variant of Jensen's inequality, JIPAM, 4 (4), (2003), article 73.

[7] J. A. Oguntuase And L. E. Persson, Time scale Hardy type inequalities via superquadracity, to appear, Ann. Func. Anal. 